\title{
CONSUMPTION AND KEYNESIAN FISCAL POLICY
}

\author{
ALFREDO SCHCLAREK
}

CESIFO WORKING PAPER NO. 1310

CAtegory 5: Fiscal Policy, Macroeconomics AND Growth

OCTOBER 2004

Presented at CESifo Venice Summer Institute, Workshop on the ReViVAL of

Aggregate Demand Management Policies: Back to Keynes?, July 2004

An electronic version of the paper may be downloaded

- from the SSRN website:

www.SSRN.com

- from the CESifo website:

www. CESifo.de 


\title{
CONSUMPTION AND KEYNESIAN FisCAL POLICY
}

\begin{abstract}
This paper empirically studies the effects of fiscal policy shocks on private consumption. Further, it tries to determine if the level of government bond yield and the unemployment rate affect that relationship. We use yearly data between 1970 and 2000 for thirty-eight countries, of which half are industrialized and half are developing countries. In general, the estimation results seem to indicate that government consumption shocks have Keynesian effects for both industrial and developing countries. In the case of tax shocks, the evidence suggest that they do not have any effects on private consumption. Furthermore, there is no evidence that favors the hypothesis of expansionary fiscal consolidations.
\end{abstract}

JEL Code: C33, E21, E62.

Keywords: fiscal policy, private consumption, government expenditure, taxation, developing countries.

\author{
Alfredo Schclarek \\ Department of Economics \\ Lund University \\ P.O. Box 7082 \\ SE-220 07 Lund \\ Sweden \\ alfredo@nek.lu.se
}

I want to thank Michael Bergman, Alex Cukierman, Anders Danielson, Marcelo Delajara, David Edgerton, Daniel Heymann, Yona Rubinstein, and Pablo Sanguinetti for comments and discussions; and seminar participants at Lund University, Universidad Nacional de Córdoba, Universidad E Siglo 21 and European Central Bank; and participants at the Applied Econometric Association Econometric of Emerging Countries conference (Toledo, Spain, 2003), I Congreso Nacional de Estudiantes de Postgrado en Economía (Bahia Blanca, Argentina, 2003), Novenas Jornadas de Economía Monetaria e Internacional (La Plata, Argentina, 2004), CESifo Workshop on "The Revival of Aggregate Demand Management Policies: Back to Keynes?" (Venice, Italy, 2004). The present study was accomplished while I was visiting Universidad E Siglo 21. 


\section{Introduction}

Since the paper by Giavazzi and Pagano (1990), there has been a resurgence in the debate on the effects of fiscal policy. Specifically, there have been a growing number of empirical studies that claim that under special circumstances contractionary fiscal policy may have expansionary effects on consumption, investment and/or output, i.e. fiscal policy has non-Keynesian effects. The most cited papers within this strand of the literature are Giavazzi and Pagano (1990), Giavazzi and Pagano (1996), Perotti (1999) and Giavazzi et al. (2000). However, there is also a growing number of studies that reject the non-Keynesian hypothesis, and claim that one should not generalise the results by Giavazzi and Pagano (1990). Among these papers one could mention, among others, Hjelm (2002b), van Aarle and Garretsen (2003) and Schclarek (2003). Clearly, the empirical results are mixed and the debate is not set yet.

On top of these mixed results, most of the cited papers have mainly focused on the experience of industrial countries. Therefore, there is little evidence that guarantees that the experience of industrial countries can be applied to developing countries. Fortunately, there is an increasing interest to include the experience of developing countries in this debate (Gavin and Perotti, 1997). Giavazzi et al. (2000) and Schclarek (2003) are a contribution in that direction. However, while Schclarek (2003) study the effects of fiscal policy on private consumption, Giavazzi et al. (2000) focus on national saving. Further, Schclarek (2003) finds that fiscal policy has Keynesian effects. Contrarily, Giavazzi et al. (2000) claim that fiscal policy has non-Keynesian results in developing countries. Thus, more research should be done in order to clarify this contradictory results.

The present work is an extension of Schclarek (2003) and empirically investigate the effects of fiscal policy on private consumption for both industrial and developing countries. Specifically, it tries to determine whether fiscal policy has Keynesian or non-Keynesian effects on private consumption and if this relationship is affected by the initial conditions of the economy. We use two variables to determine the initial conditions of the economy, namely the interest rate that the bonds issued by the government pay and the rate of unemployment. The use of these two variables is the main difference with Schclarek (2003), who study the nonlinear relationship taking into account the level of public debt and the size of the public deficit. The econometric methodology of the present study is based on panel data estimation, using a yearly panel of thirty eight countries, of which 19 are industrialized and 19 are developing countries. Further, the data spans between 1970 and 2000. The sources of the data are the World Development Indicators 2002 database of World Bank and the International Financial Statistics 2002 database of the IMF.

The rest of the paper is organized in seven sections. Section 2 presents a short survey of the empirical literature. The theoretical model used as a basis for the empirical research is briefly described in section 3. The empirical methodology and the data used are discussed in sections 4 and 5 respectively. Section 6 presents the estimation results for the whole sample, the sample of industrial countries and the sample of developing countries. In section 7 , we discuss and 
present the results from some consistency test that were made in order to confirm the results from the benchmark case. Finally, section 8 concludes.

\section{Survey of the literature}

The literature that has evolved since the paper by Giavazzi and Pagano (1990), have mainly tried to answer whether fiscal policy has Keynesian or non-Keynesian effects on economic activity. Further, it has tried to answer under which special conditions fiscal policy has non-Keynesian effects. According to this branch of the economic literature, the impact of fiscal policy depends on: (i) the sign of the impulse (budget cut or expansion); (ii) its size and duration; (iii) the initial conditions (previous level or rate of growth of public debt, preceding exchange rate and money supply movements); (iv) the composition of the impulse (changes in taxes and transfers relative to changes in government consumption, changes in public investment or in social security entitlements).

Hemming et al. (2002) make an extensive survey of the theoretical and empirical literature on the effectiveness of fiscal policy in stimulating economic activity. They conclude that in general fiscal policy have Keynesian effects on economic activity but that the multiplying effect is small. Further, they acknowledge the possibility of non-Keynesian effects. In what follow we will extend the review of the empirical literature made by Hemming et al. (2002) in order to incorporate the latest results within the field. Specifically, we will concentrate our survey on those papers that examine cross section of countries in order to determine the existence, or not, of expansionary fiscal contractions. In general, the latest studies tend to cast doubts about the expansionary fiscal contraction hypothesis.

Table 1 summarizes the main conclusions from the surveyed papers. In this table we have also included the results of Giavazzi and Pagano (1996), Perotti (1999), and Giavazzi et al. (2000), which are the most cited articles in the empirical literature. The main conclusions of the surveyed studies for industrial countries are as follow:

- The evidence tends not to support the expansionary fiscal contraction hypothesis. The only exception is Jönsson (2004), who finds that when fiscal contractions, in terms of public transfers, are large and persistent, there are non-Keynesian results. All the other studies obtain results that favor the view that fiscal policy has Keynesian effects.

- Regarding the sign of the impulse, the evidence seems to favor the asymmetry between contractions and expansions. Hjelm (2002b) find that private consumption grows less during contractions compared to normal periods and that there is no difference between expansions and normal times. In addition, Jönsson (2004) finds non-Keynesian effects for public transfers during contractions and Keynesian effects during expansions.

- Initial conditions are not important with the exception of the preceding exchange rate movement. Hjelm (2002a) and Hjelm (2002b) find that 
contractions preceded by real depreciations improve consumption growth compared to contractions preceded by real appreciations.

- With respect to the composition of the impulse, the evidence is mixed. While van Aarle and Garretsen (2003) find that public transfers have clearer Keynesian effects than government spending and taxes, Jönsson (2004) finds that public transfers have non-Keynesian effects during contractions. In addition, Schclarek (2003) finds that government consumption has Keynesian effects while taxes do not have any effects. Further, Hjelm (2002b) concludes that the composition is not important.

- With the exception of van Aarle and Garretsen (2003), there are no studies that focus on the effects of fiscal policy on investment. They conclude that the findings for private consumption can be extended to private investment, i.e. fiscal policy has Keynesian effects on investment.

Concluding, we can say that the fact that there have been episodes of expansionary fiscal contractions, and that some episodes share certain characteristics is not rejected. However, the surveyed papers cast doubts about the generality of these results. Furthermore, as the paper by Hjelm (2002a) shows, the preceding exchange rate movement is a key element for fiscal contractions to become successful. The most cited examples of successful expansionary fiscal contractions, namely Denmark (1982-1986) and Ireland (1987-1989), where all preceded by real exchange rate depreciations. Thus, it is possible that it was the real exchange rate depreciation that caused the consumption growth rather than the contractionary fiscal policy.

When considering the effects of fiscal policy for developing countries, the evidence is limited to the work of Giavazzi et al. (2000) and Schclarek (2003). Moreover, the evidence of non-Keynesian effects is mixed. On one side, Giavazzi et al. (2000) find evidence of non-linear effects of fiscal policy on private savings during large changes in the surplus. Furthermore, when large changes in the surplus are preceded by rapid debt growth, they even find non-Keynesian effects of taxes on private savings. On the other hand, Schclarek (2003) does not find any evidence for developing countries that support the expansionary fiscal contraction hypothesis. Furthermore, he finds that both government consumption and tax shocks have Keynesian effects on private consumption and that the coefficients are larger for developing countries in comparison to industrial countries.

\section{$3 \quad$ Theoretical Model}

In this section we will briefly outline the theoretical model that we will use as point of reference for our empirical investigation. For a detailed treatment of the theoretical model we make reference to Perotti (1999). The model has four basic assumptions: first, taxes have distortionary effects; second, the government has a higher discount rate than private agents, and thus the economy is initially away 


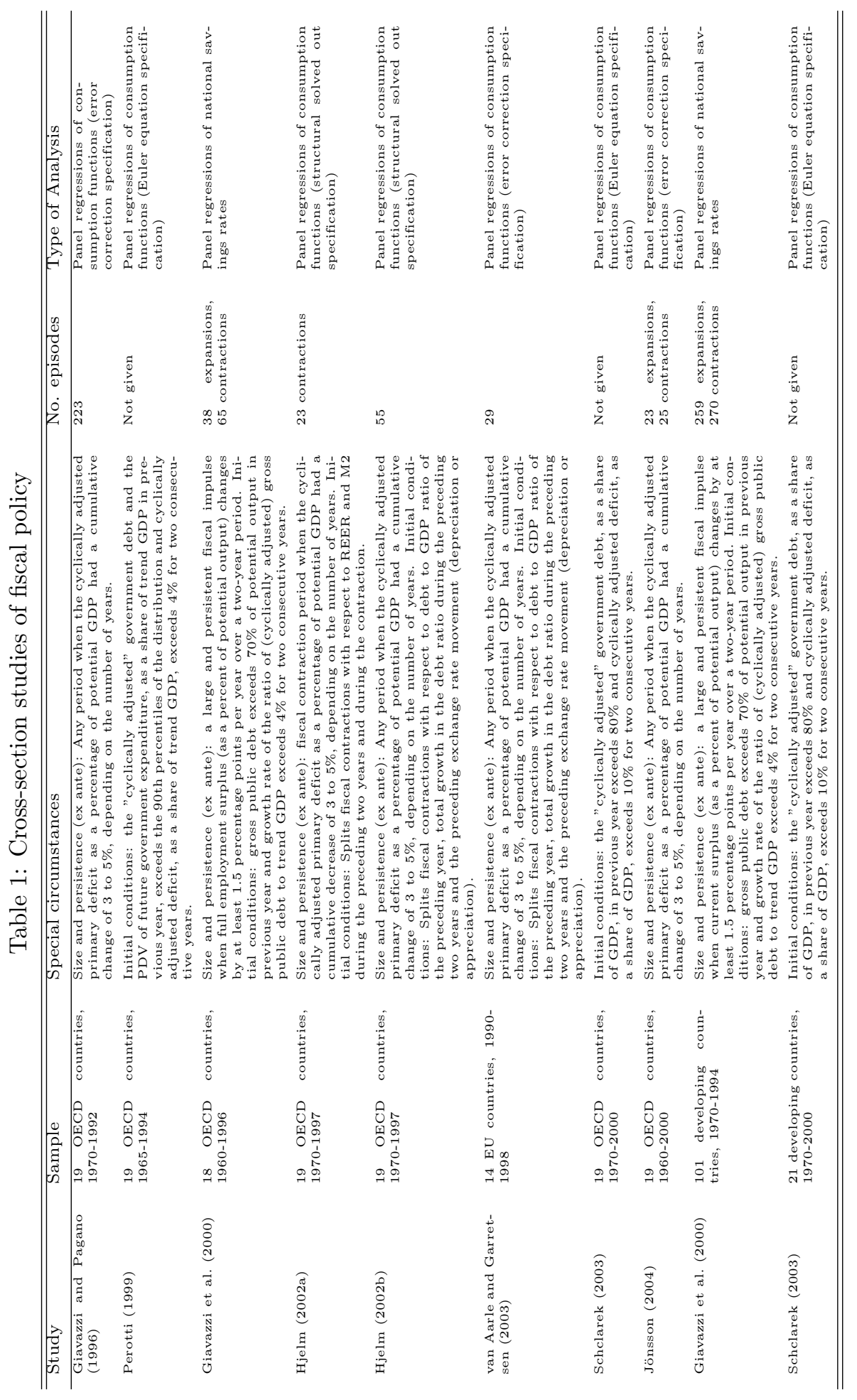




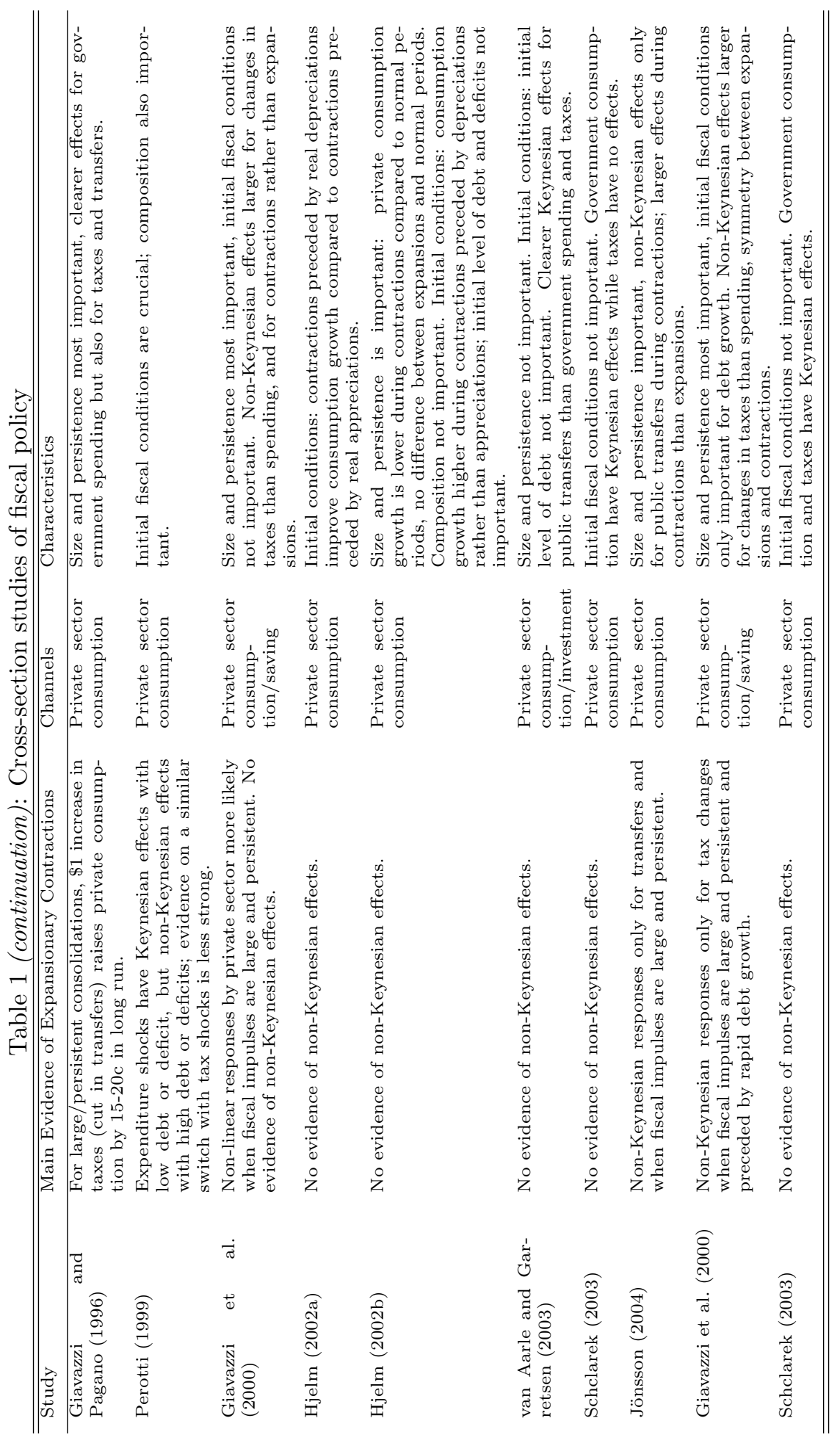


from a perfect tax-smoothing situation; third, there are two kinds of private agents in terms of the access to the credit market, unconstrained individuals and constrained individuals; fourth, government consumption has positive effects on economic output.

There is a fraction $1-u$ of unconstrained individuals, which have perfect access to the credit market. The fraction $u$ of constrained individuals have no access to the credit market. Both kinds of agents live for three periods. The model study the change in their consumption between periods 0 and 1 due to a fiscal shock in period 1. Further, the response of the fiscal policy in period 2 will depend on the fiscal shock in period 1. Therefore, fiscal policy shocks will have wealth effects from anticipated future responses of fiscal policy for unconstrained individuals. Conversely, constrained individuals will have no wealth effects and their change in consumption between periods 0 and 1 will be completely determined by their current income, which in turn is affected by the fiscal shock.

Further, $L_{t}$ is the PDV of the financing needs of the government, which is determined by the intertemporal government budget constraint. Moreover, $p$ is the probability that the policy-maker currently in charge of the government stay in office in the next period. The case when $L_{t}$ is low or $p$ is high is denominated good times, and the opposite situation is called bad times. According to this model, government consumption shocks have positive effects on private consumption at low levels of $L_{0}$, the PDV of the financing needs from the perspective of time 0 , and negative effects at high levels of it. Similarly, government consumption shocks have positive effects at high levels of $p$ and negative effects at low levels of it. In the case of tax revenue shocks, the model predicts that the tax shocks have the opposite effects on private consumption than the government consumption shocks. Therefore, tax shocks have negative effects at low levels of $L_{0}$, or high levels of $p$, and positive effects at high levels of $L_{0}$, or low levels of $p$. These predictions of the model will be the null hypothesis that we will empirically test. Further, the empirical model for testing the null hypothesis will be presented in the next section.

\section{$4 \quad$ Specification and Estimation Methodology}

The empirical model that we will estimate is a two-step econometric model. In the first step, we will estimate the fiscal policy innovations and the expected change in disposable income for each country at the time. After that, we will use the generated regressors to estimate the structural equation, which is the model we are interested in, through panel data estimation. We will estimate two different structural equations: the first one reflects the fiscal policy effects on consumption for both constrained and unconstrained individuals, and the second reflects only the effects on unconstrained individuals. The first structural equation model is

$$
\Delta C_{i t}=\gamma_{1} \hat{\epsilon}_{i t}^{G}+\tilde{\gamma}_{1} D_{i t} \hat{\epsilon}_{i t}^{G}+\gamma_{2} \hat{\epsilon}_{i t}^{T}+\tilde{\gamma}_{2} D_{i t} \hat{\epsilon}_{i t}^{T}+\mu \Delta \hat{Y}_{i t / t-1}+\omega_{i t}
$$


where $\Delta C_{i t}$ is the change in private consumption for country $i$ at time $t, \hat{\epsilon}_{t i}^{G}$ is the estimated shock, or innovation, in government consumption, $\hat{\epsilon}_{i t}^{T}$ is the estimated shock in tax revenues, $D_{i t}$ is a dummy variable, which will take the value 0 in good times and the value 1 in bad times, $\Delta \hat{Y}_{i t / t-1}$ is the estimated change in disposable income using information at time $t-1$, and $\omega_{i t}$ is the error term.

The coefficient $\gamma_{1}$ measures the effects of government consumption shocks on the consumption of both constrained and unconstrained individuals. The case when $\gamma_{1}>0$ is referred as the Keynesian effects of government consumption because a positive government consumption shock has a positive effect on private consumption. Conversely, when $\gamma_{1}<0$ we say that government consumption has non-Keynesian effects on private consumption. Similarly, when $\gamma_{2}$ has a negative sign it means that a tax shock has a negative effect on private consumption. In this case, $\gamma_{2}<0$ is referred as the Keynesian effect and $\gamma_{2}>0$ as the nonKeynesian effect. The expansionary effects of fiscal consolidations occur when $\gamma_{1}<0$ and/or $\gamma_{2}>0$. The coefficients $\tilde{\gamma}_{1}$ and $\tilde{\gamma}_{2}$ measure the difference in the effects of government consumption shocks and tax shocks between good and bad times respectively.

Under the null hypothesis $\gamma_{1}>0, \tilde{\gamma}_{1}<0, \gamma_{2}<0$, and $\tilde{\gamma}_{2}>0$. Therefore, the null hypothesis states that fiscal policy innovations have normally Keynesian effects on private consumption but that the Keynesian effects are reduced in bad times. Moreover, in the case that $\tilde{\gamma}_{1}>\gamma_{1}$ and/or $\tilde{\gamma}_{2}>\gamma_{2}$ the Keynesian effects are reverted in bad times and therefore fiscal policy shocks have non-Keynesian effects, i.e. the expansionary effects of fiscal consolidations.

The second structural equation, which reflects the fiscal policy effects on consumption but only for unconstrained individuals, is

$$
\Delta C_{i t}=\gamma_{1}^{u} \hat{\epsilon}_{i t}^{G}+\tilde{\gamma}_{1}^{u} D_{t} \hat{\epsilon}_{i t}^{G}+\gamma_{2}^{u} \hat{\epsilon}_{i t}^{T}+\tilde{\gamma}_{2}^{u} D_{t} \hat{\epsilon}_{i t}^{T}+\mu \Delta \hat{Y}_{i t / t}+\tilde{\omega}_{i t}
$$

where $\Delta \hat{Y}_{i t / t}$ is the forecasted change in disposable income for country $i$ using information at time $t$. Also the $u$ reflects the fact that we are only analyzing the effects of fiscal policy shocks on unconstrained individuals. Therefore, this alternative approach permits us study the wealth effects of unconstrained individuals which is the source of the non-Keynesian effects of fiscal policy. Note that the difference between equations (1) and (2) is that the first use $\Delta \hat{Y}_{i t / t-1}$ while the second use $\Delta \hat{Y}_{i t / t}$. The difference between $\Delta \hat{Y}_{i t / t-1}$ and $\Delta \hat{Y}_{i t / t}$ is that the later use both lagged information on disposable income and the contemporaneous estimated fiscal policy innovations (Schclarek, 2003). Therefore, $\Delta \hat{Y}_{i t / t}$ incorporates the effects of fiscal shocks on the disposable income of constrained individuals, and thus the coefficients of the fiscal innovations in equation (2) reflects only the wealth effects on consumption for unconstrained individuals (Perotti, 1999).

Under the null hypothesis $\gamma_{1}^{u}<\gamma_{1}, \tilde{\gamma}_{1}^{u}=\tilde{\gamma}_{1}<0, \gamma_{2}^{u}>0>\gamma_{2}$, and $\tilde{\gamma}_{2}^{u}>\tilde{\gamma}_{2}>0$. The null hypothesis states that during normal times a government consumption shock will have a milder effect on the consumption of unconstrained individuals than when taking into account both kinds of individuals. 
The reason is that unconstrained individuals decide their present consumption taking into account the PDV of income and not only their present income as constrained individuals do. Therefore, when government consumption increase, unconstrained individuals also take into account that in the future the tax revenues of the government will have to increase to finance the current increase in government consumption, thus having a negative wealth effect. $\tilde{\gamma}_{1}^{u}$ is equal to $\tilde{\gamma}_{1}$ because it is only unconstrained individuals that react differently between bad times and good times. The reason for $\gamma_{2}^{u}$ being positive is that tax distortions fall, and therefore the wealth of unconstrained individuals increase, when current taxation is increased and future taxation is reduced, at the same time that the expected PDV of taxation is constant. Further, $\tilde{\gamma}_{2}^{u}>\tilde{\gamma}_{2}>0$ because $\tilde{\gamma}_{2}=\tilde{\gamma}_{2}^{u}+\tilde{\gamma}_{2}^{c}$ and $\tilde{\gamma}_{2}^{c}<0$ (Perotti, 1999).

Both equation (1) and (2) were estimated using two alternative definitions for the dummy variable. In addition, they were estimated for the whole country sample but also for the sub-sample of industrialized countries and the subsample of developing countries. The estimation method that was used was the fixed effect panel data version of the Prais-Winsten estimator. ${ }^{1}$ In all the regressions we included year dummies to account for any time-specific effects, i.e. we had a two-way error component regression model. In addition, for all regressions we allowed the disturbances to be heteroskedastic and contemporaneously correlated across panels (each pair of panels has their own covariance). Further, we specified that within panels, there was first-order autocorrelation and that the coefficient of the $\mathrm{AR}(1)$ process was specific to each panel. ${ }^{23}$

As noted earlier, $\hat{\epsilon}_{i t}^{G}, \hat{\epsilon}_{i t}^{T}, \Delta \hat{Y}_{i t / t-1}$, and $\Delta \hat{Y}_{i t / t}$ are generated regressors, which are obtained from the first-step model for each country at the time. According to McAleer and McKenzie (1991) the presence of generated regressors results in the covariance matrix of the disturbance term being non-spherical, with both nonzero off-diagonal and non-constant diagonal elements. Obviously, these poses a problem for our panel data estimation methodology, which unfortunately has no easy solution. ${ }^{4}$ However, the estimation procedure that we used provides an efficient estimator (McAleer and McKenzie, 1991). ${ }^{5}$ Moreover, as will be clearer

\footnotetext{
${ }^{1}$ According to Beck and Katz (1995) the Prais-Winston estimator used in our regressions produces more accurate standard errors than the commonly used feasible generalized least square (FGLS) estimator.

${ }^{2}$ We tested our data for heteroskedasticity and autocorrelation for both equation (1) and (2) using the two dummy variable definitions. The tests performed were a modified Wald test for groupwise heteroskedasticity and a LM test for first-order serial correlation. For the sample of all countries and the sub-sample of industrial countries, we found evidence of both heteroskedasticity and autocorrelation when we used the dummy variable $D 2_{t}$. Yet, when we used the dummy variable $D 1_{t}$, we found heteroskedasticity but not autocorrelation. For de sub-sample of developing countries, we found both heteroskedasticity and autocorrelation when using both dummy variables. However, in order to take care of the "generated regressor" problem, we estimated all equations allowing for autocorrelation.

${ }^{3}$ We used the estimation command "xtpcse" with the "correlation(psar1)" option from the statistical software Stata 7.0.

${ }^{4}$ See, for example, Pagan (1984), Murphy and Topel (1985), McAleer and McKenzie (1991), and Smith and McAleer (1994).

${ }^{5}$ There are two broad procedures to correct the standard errors for the "generated regressor" problem. The first procedure implies applying a joint estimation method, such as full
} 
when the empirical results are presented, even if we use incorrect standard errors our main results cannot be invalidated. ${ }^{6}$

\section{Data}

The sample used for the estimation of the model consisted of a yearly panel of thirty eight countries, half of them were industrialized countries and the other half developing countries. ${ }^{7}$ The sources of the data are the World Development Indicators 2002 database from the World Bank and the International Financial Statistics 2002 of the IMF. A detailed description of the definitions and sources for the different variables used in the present study are presented in table 2 . The data span from 1970 to 2000, i.e. there are 31 observations for each country. However, the transformations of the data and estimation procedures reduced the span of the sample with four observations. Besides, we used unbalanced panels because for certain countries there was not complete data for the dummy variables.

All the variables are scaled by the lagged value of disposable income. The procedure is described in detail in Schclarek (2003). The reason for not using the standard scaling procedure, which uses the log value of the variable, is that there are large differences in government consumption-to-GDP and tax-toGDP ratios across countries and over time. Obviously a change in government consumption will not have the same effects on private consumption if the government consumption-to-GDP ratio is $10 \%$ as when it is $30 \%$. Therefore just scaling by the log difference is not appropriate in this case

As mentioned in section 4, the fiscal policy innovations $\hat{\epsilon}_{i t}^{G}$ and $\hat{\epsilon}_{i t}^{T}$ are not readily available and had to be estimated, i.e. they are generated regressors. In addition, the fiscal policy shocks have been cyclically adjusted, because we are only interested in the discretionary variations and not the variations due to the business cycle. The estimation method and the cyclical adjustments are described in detail in Schclarek (2003).

In the case of the empirical construction of the regime dummy variable, $D_{i t}$ takes the value 0 in good times and the value 1 in bad times. Further, as in the theoretical model in section 3 we used two different definitions of bad times. $D 1_{t}$

information maximum likelihood (FIML). The other alternative, which is the one employed in this study, is to use a two-step estimator. In this case, the standard errors from the second step need to be corrected. In this study, we have corrected the standard errors by allowing them to be heteroskedastic and autocorrelated of order 1.

${ }^{6}$ As Murphy and Topel (1985) show, the correct covariance matrix for the second-step estimators exceeds the unadjusted covariance matrix by a positive-definite matrix. Therefore, unadjusted standard errors are understated. In our case, and because in most cases we cannot reject the null of insignificant coefficients, this would imply that most of our coefficient would become even more insignificant.

${ }^{7}$ The industrialized economies are Australia, Austria, Belgium, Canada, Denmark, Finland, France, Germany, Greece, Ireland, Italy, Japan, Netherlands, Norway, Portugal, Spain, Sweden, United Kingdom, and United States. The developing countries are Chile, Colombia, Costa Rica, Dominican Republic, Malaysia, Malta, Mexico, Morocco, Pakistan, Panama, Paraguay, Philippines, South Africa, Sri Lanka, Thailand, Turkey, Uruguay and Venezuela. 
Table 2: Definitions and sources of the variables

\begin{tabular}{llc}
\hline \hline Variables & Series & Sources \\
\hline Private consumption & Final Household Consumption Expenditure & WDI \\
Government consumption & General Final Govt. Consumption Expend. & WDI \\
Total tax revenue & Taxes on Income, Profits and Capital Gains & WDI \\
& + Social Security Taxes & WDI \\
& + Net Taxes on Products & WDI \\
Households disposable income & GNI & WDI \\
Gross domestic product & GDP & WDI \\
Disposable income deflator & GDP Deflator & WDI \\
Population & Population, total & WDI \\
Government bond yield & Government Bond Yield & IFS \\
Unemployment rate & Unemployment, total (\% of total labor force) & WDI \\
\hline \hline
\end{tabular}

was used as proxy for $L_{0}$ and $D 2_{t}$ for $p$. In the first definition, $D 1_{t}$, we used the long term government bond yield to define bad times. Specifically, bad times are those years $t$ in which the bond yield in the previous period $t-1$ is higher than a certain threshold value $x$. The aforementioned value $x$ is determined individually for each country of the sample and corresponds, in the benchmark case, to the eightieth percentile of the distribution for each country. As will be seen in section 7 , we will also take alternative values for $D 1_{t}$, equivalent to the seventieth and ninetieth percentiles, in order corroborate our results obtained in the benchmark case.

In second definition of bad times, $D 2_{t}$, we used the unemployment rate for every country to define bad times. In this case, a given year $t$ belongs to the bad times regim if a country's unemployment rate exceeds a certain value $x$ in the previous year $t-1$. we use the same methodology for $D 2_{t}$ as for $D 1_{t}$, that is the seventieth, eightieth and ninetieth percentiles, where the eightieth percentile also serves as the benchmark case. In table 3 of the appendix, we see a list of the country-years that belong to the bad time regime according to the definitions of $D 1_{t}(.80), D 1_{t}(.90), D 2_{t}(.80)$, and $D 2_{t}(.90)$.

\section{$6 \quad$ Estimation Results}

\subsection{All the Countries in the Panel}

Table 4 shows the estimates of equation (1) in columns (1) and (2), and of equation (2) in columns (3) and (4) for all the countries in the sample. Thus, the estimated coefficients are the $\gamma_{i}{ }^{\prime}$ 's and $\tilde{\gamma}_{i}$ 's in columns (1) and (2) and $\gamma_{i}^{u}$ 's and $\tilde{\gamma}_{i}^{u}$ 's in columns (3) and (4). The difference between columns (1) and (2) is 
Table 3: Bad times

\begin{tabular}{|c|c|c|c|c|}
\hline & $\begin{array}{c}(1) \\
D 1_{t}(.80)\end{array}$ & $\begin{array}{c}(2) \\
D 1_{t}(.90)\end{array}$ & $\begin{array}{c}(3) \\
D 2_{t}(.80)\end{array}$ & $\begin{array}{c}(4) \\
D 2_{t}(.90)\end{array}$ \\
\hline Australia & 1981-1986 & $\begin{array}{l}1981-1982, \\
1985\end{array}$ & $\begin{array}{l}1983,1991- \\
1993\end{array}$ & $1992-1993$ \\
\hline Austria & $\begin{array}{l}\text { 1974-1976, } \\
1980-1982\end{array}$ & $\begin{array}{l}1974,1981- \\
1982\end{array}$ & $\begin{array}{l}1986,1996- \\
1998\end{array}$ & 1996.1998 \\
\hline Belgium & 1980-1985 & 1980-1982 & 1982-1984 & 1982,1984 \\
\hline Canada & $1980-1985$ & $\begin{array}{l}\text { 1981-1982, } \\
1984\end{array}$ & $\begin{array}{l}1983-1984 \\
1992-1993\end{array}$ & 1983, 1993 \\
\hline Chile & & & $1982-1985$ & $1982-1983$ \\
\hline Colombia & & & $\begin{array}{l}1985,1998- \\
2000\end{array}$ & $1999-2000$ \\
\hline Costa Rica & & & $\begin{array}{l}1981-1983, \\
1985\end{array}$ & $1982-1983$ \\
\hline Denmark & $\begin{array}{l}1974,1978- \\
1982\end{array}$ & 1980-1982 & $\begin{array}{l}\text { 1981-1983, } \\
1993\end{array}$ & 1982,1993 \\
\hline Dominican Republic & & & $1992-1993$ & 1992 \\
\hline Finland & & & $1993-1996$ & 1993-1994 \\
\hline France & $1980-1985$ & 1981-1983 & $\begin{array}{l}1994,1996- \\
1997\end{array}$ & 1994,1997 \\
\hline Germany & $\begin{array}{l}1974,1981- \\
1982,1990- \\
1991\end{array}$ & 1974,1981 & $1997-1998$ & 1997 \\
\hline Greece & & & $\begin{array}{l}1996,1998- \\
2000\end{array}$ & 1999-2000 \\
\hline Ireland & $\begin{array}{l}\text { 1974, 1976, } \\
1979-1982\end{array}$ & $\begin{array}{l}1974,1981- \\
1982\end{array}$ & $1985-1988$ & $1986-1987$ \\
\hline Italy & $\begin{array}{l}1977,1980- \\
1984\end{array}$ & $1981-1983$ & $\begin{array}{l}\text { 1987-1989, } \\
1998\end{array}$ & 1988-1989 \\
\hline Japan & $\begin{array}{l}1974-1976 \\
1980-1982\end{array}$ & $\begin{array}{l}\text { 1974-1975, } \\
1980\end{array}$ & $1998-2000$ & $1999-2000$ \\
\hline Malaysia & & & $1985-1988$ & $1986-1987$ \\
\hline Malta & & & $1983-1986$ & $1983-1984$ \\
\hline Mexico & & & $1994-1996$ & $1995-1996$ \\
\hline Morocco & & & $\begin{array}{l}\text { 1994-1995, } \\
1999\end{array}$ & 1995,1999 \\
\hline Netherlands & $\begin{array}{l}1974,1976, \\
1980-1982, \\
1990\end{array}$ & 1980-1982 & $1983-1986$ & $1983-1984$ \\
\hline Norway & $\begin{array}{l}\text { 1982-1983 } \\
1985-1988\end{array}$ & $\begin{array}{l}1982,1986- \\
1987\end{array}$ & 1991-1994 & 1993 \\
\hline Pakistan & $1978-1983$ & $1978-1980$ & 1991, 1997 & 1991, 1997 \\
\hline Panama & & & $1988-1991$ & 1988-1989 \\
\hline Paraguay & & & $\begin{array}{l}1983-1984 \\
1990,1996\end{array}$ & 1983,1996 \\
\hline Philippines & & & $\begin{array}{l}1987,1998- \\
2000\end{array}$ & 2000 \\
\hline
\end{tabular}


Table 3 (continuation): Bad times

\begin{tabular}{lcccc}
\hline \hline & \multicolumn{1}{c}{$(1)$} & \multicolumn{1}{c}{$(2)$} & \multicolumn{1}{c}{$(3)$} & \multicolumn{1}{c}{$(4)$} \\
& $D 1_{t}(.80)$ & $D 1_{t}(.90)$ & $D 2_{t}(.80)$ & $D 2_{t}(.90)$ \\
\hline Portugal & $1982-1985$, & $1983-1985$ & $1983-1986$ & $1985-1986$ \\
& $1990-1991$ & & & \\
South Africa & $1985-1986$, & $1985,1988-$ & & \\
Spain & $1988-1991$ & 1989 & & $1994-1995$ \\
Sri Lanka & $1980-1984$ & $1982-1984$ & $1993-1996$ & 1993 \\
Sweden & & & 1990,1993 & $1993-1997$ \\
& $1981-1983$, & 1981,1985, & $1993-1994$, & $1996-1997$ \\
Thailand & 1985,1990 & 1990 & $1996-1997$ & \\
& $1979-1982$, & $1979,1981-$ & $1985-1987$, & 1985,1987 \\
Turkey & 1984 & 1982 & 1998 & \\
United Kingdom & $1974-1976$, & 1974,1976, & $1983-1986$ & 1984 \\
& $1979-1981$ & 1981 & & \\
United States & $1980-1985$ & $1981-1982$, & $1981-1983$ & $1982-1983$ \\
& & 1984 & & \\
Uruguay & $1994-1996$, & $1994-1995$ & $1984-1985$, & 1985,1999 \\
Venezuela & 1998 & & 1996,1999 & \\
Observations & 120 & 61 & 128 & 66 \\
\hline \hline
\end{tabular}

In the first definition of bad times, $D 1_{t}$, we use government bond yield to define bad times. In second definition of bad times, $D 2_{t}$, we use the unemployment rate to define bad times. Bad times are those years $t$ in which the interest rate or the unemployment rate in the previous period $t-1$ is higher than a certain threshold value $x . x$ is determined individually for each country of the sample and corresponds to the eightieth and ninetieth percentile of the distribution for each country. In columns (1) and (3) we use the eightieth percentile and in columns (2) and (4) we use the ninetieth percentile. In section 5 we discuss the construction of the the bad times's dummy variable. 
that the dummy variable used is $D 1_{t}(.80)$ and $D 2_{t}(.80)$ respectively. The same apply to columns (3) and (4).

In columns (1) and (2) under the null hypothesis $\gamma_{1}>0, \tilde{\gamma}_{1}<0, \gamma_{2}<0$, and $\tilde{\gamma}_{2}>0$. Examining column (1), when the first definition of bad times $D 1_{t}(.80)$ is used, we see than the only coefficients that are consistent with the null hypothesis are $\gamma_{1}$ and $\gamma_{2}$. The coefficient for government consumption is 0.887 and is significantly different from zero at the $1 \%$. Consequently, government consumption shocks have Keynesian effects on private consumption in good times. Besides, $\tilde{\gamma}_{1}$ is insignificantly different from zero and inconsistent with the null hypothesis. As a consequence, there is no difference in the Keynesian effects between good and bad times. In the case of the tax shocks during good times, the coefficient $\gamma_{2}$ is significant at the $5 \%$ and take the value -0.235 . Besides, $\tilde{\gamma}_{2}$ is insignificant and not consistent with the null hypothesis. Therefore, tax shocks have Keynesian effects on private consumption during good times as well as during bad times.

When using the second definition for bad times $D 2_{t}(.80)$ in column (2), the only significant coefficient is $\gamma_{1}$ with a value equal to 0.676 . Because $\tilde{\gamma}_{1}$ is insignificantly, government consumption shocks have Keynesian effects in good and bad times. On the other hand, both coefficients of the tax variable are insignificantly different from zero. Consequently, tax shocks have no effects on private consumption during good and bad times.

In the case of columns (3) and (4) the null hypothesis states that $\gamma_{1}^{u}<\gamma_{1}$, $\tilde{\gamma}_{1}^{u}=\tilde{\gamma}_{1}<0, \gamma_{2}^{u}>0>\gamma_{2}$, and $\tilde{\gamma}_{2}^{u}>\tilde{\gamma}_{2}>0$. Note that now the coefficients of the fiscal shocks depict only the effects on unconstrained individuals. In column (3) we see that the only coefficients that are consistent with the null hypothesis are $\gamma_{1}^{u}$ and $\gamma_{2}^{u}$. The coefficient for government consumption is significant and has a value of 0.452 , which is inferior to the value of $\gamma_{1}(0.887)$. In addition, the coefficient $\gamma_{2}^{u}$, which reflects tax shocks in good times, is equal to -0.246 and significant at the $1 \%$. The results of column (4) are also mostly inconsistent with the null hypothesis. In this case, only the coefficient for government consumption shocks is significant and equal to 0.597 . The rest of the coefficients are insignificantly different to zero.

In short, the results using the entire panel of countries seem not to be consistent with the null hypothesis. Specifically, government consumption shocks have Keynesian effects in good times as well as in bad times. Also, the estimates of the tax variable yield ambiguous results. When we define bad times using the government bond yield, we find that tax shocks have Keynesian effects during good and bad times. However, when we use the rate of unemployment, the estimates show that tax shocks have no effects on private consumption. In addition, there is no evidence that supports the expansionary fiscal consolidations hypothesis. Also, when comparing the results from equation (1) and (2), we do not find any significant differences in the results. Thus, we conclude that unconstrained and constrained individuals react in the same way on fiscal policy shocks. 
Table 4: Estimates All Countries

\begin{tabular}{lllllll}
\hline \hline Var. & Coef. & \multicolumn{1}{c}{$(1)$} & \multicolumn{1}{c}{$(2)$} & Coef. & \multicolumn{1}{c}{$(3)$} & \multicolumn{1}{c}{$(4)$} \\
\hline$\hat{\epsilon}_{t}^{G}$ & $\gamma_{1}$ & 0.887 & 0.676 & $\gamma_{1}^{u}$ & 0.452 & 0.597 \\
& & $(0.221)^{* * *}$ & $(0.177)^{* * *}$ & & $(0.206)^{* *}$ & $(0.172)^{* * *}$ \\
$D_{t} * \hat{\epsilon}_{t}^{G}$ & $\tilde{\gamma}_{1}$ & 0.147 & 0.339 & $\tilde{\gamma}_{1}^{u}$ & 0.135 & 0.103 \\
& & $(0.496)$ & $(0.422)$ & & $(0.470)$ & $(0.402)$ \\
$\hat{\epsilon}_{t}^{T}$ & $\gamma_{2}$ & -0.235 & -0.056 & $\gamma_{2}^{u}$ & -0.246 & -0.060 \\
& & $(0.093)^{* *}$ & $(0.095)$ & & $(0.089)^{* * *}$ & $(0.090)$ \\
$D_{t} * \hat{\epsilon}_{t}^{T}$ & $\tilde{\gamma}_{2}$ & 0.072 & -0.081 & $\tilde{\gamma}_{2}^{u}$ & 0.055 & -0.150 \\
& & $(0.212)$ & $(0.199)$ & & $(0.205)$ & $(0.179)$ \\
$\Delta \hat{Y}_{t / t-1}$ & $\mu$ & 0.492 & 0.364 & & & \\
& & $(0.064)^{* * *}$ & $(0.075)^{* * *}$ & & & \\
$\Delta \hat{Y}_{t / t}$ & & & & $\mu$ & 0.540 & 0.472 \\
& & & & & $(0.047)^{* * *}$ & $(0.052)^{* * *}$ \\
Sample & & All & All & & All & All \\
No. observations & & 540 & 666 & & 540 & 666 \\
No. countries & 21 & 37 & & 21 & 37 \\
$R^{2}$ & 0.294 & 0.171 & & 0.401 & 0.274 \\
Defn. of bad times & & $D 1_{t}(.80)$ & $D 22_{t}(.80)$ & & $D 1_{t}(.80)$ & $D 2 t(.80)$ \\
No. of bad times & 120 & 128 & & 120 & 128 \\
\hline \hline
\end{tabular}

Estimated using Prais-Winston regression assuming disturbances are heteroskedastic and contemporaneously correlated across panels, and allowing for panel-specific first-order autocorrelation. All regressions include year dummies to account for any time-specific effect, i.e. we have a two-way error component regression model. Columns (1) and (2) display estimates of equation (1). Columns (3) and (4) display estimates of equation (2). Standard errors in

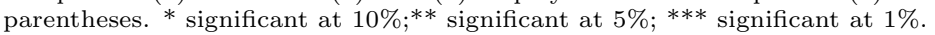




\subsection{Industrialized Countries}

Table 5 shows the estimates of equations (1) and (2) for industrialized countries. From column (1), we see that the only coefficient that is significant, is the one for government consumption shocks, with a positive value of 0.561. All the other coefficients are insignificantly different from zero and, consequently, are not according to the null hypothesis. In the case of column (2), when we use the dummy variable $D 2_{t}(.80)$, the results are similar to the results of column (1). The coefficient of government consumption shock is the only one that it is significantly different to zero and consistent with the null hypothesis, with a positive value of 0.308 .

When considering the effects of fiscal policy shocks on unconstrained individuals and using the dummy variable $D 1_{t}(.80)$ (column 3 ), the results are also mostly inconsistent with the null hypothesis. In this case, and like in columns (1) and (2), only the government consumption shocks have significant effects on private consumption. The estimate of $\gamma_{1}^{u}$ is significant at the $5 \%$ and equal to 0.372 , which is less than the estimate of $\gamma_{1}(0.561)$. In addition, $\tilde{\gamma}_{1}^{u}$ is insignificantly different from zero, and thus there are no difference in the effects of the shocks during good times and bad times. In the case of the tax variables, both coefficients are insignificantly different of zero. When using the second definition of bad times (column (4)), all the coefficients are insignificantly different from zero.

Concluding, the results for the industrial countries seem not to favor the null hypothesis. The shocks in the consumption of the government have Keynesian effects, which is consistent with the null hypothesis. However, these Keynesian effects are not reverted in bad times, which is not in agreement with the null hypothesis. Besides, in the case of the tax variable, the shocks seem not to have any effects on private consumption during good and bad times. On the other hand, when comparing the estimates of equations (1) and (2), we did not find significant differences in the results. Thus, there is no evidence that fiscal policy shocks affect differently unconstrained and constrained individuals. As a consequence, we conclude that fiscal policy have not non-Keynesian effects on private consumption.

If we compare the results of tables 4 and 5 for the dummy variable $D 1_{t}(.80)$ (columns (1) and (3)), we see that the coefficient $\gamma_{2}$ is significant for the sample of all countries and insignificant when only considering industrial countries. ${ }^{8}$ Therefore, we can conclude that the estimation results of $\gamma_{2}$, when using the sample of all countries, is significantly influenced by the effects of the developing countries. In other words, the effects of tax shocks change from not having any effect, when using the sample of industrial countries, to having Keynesian effects, when adding four developing countries to the sample of industrial countries.

\footnotetext{
${ }^{8}$ Note that the difference between this two samples are four countries. The sample of all countries consists of the sample of industrial countries plus Pakistan, South Africa, Thailand and Venezuela.
} 
Table 5: Estimates Industrial Countries

\begin{tabular}{|c|c|c|c|c|c|c|}
\hline Var. & Coef. & (1) & (2) & Coef. & (3) & (4) \\
\hline$\hat{\epsilon}_{t}^{G}$ & $\gamma_{1}$ & $\begin{array}{l}0.561 \\
(0.179)^{* * *}\end{array}$ & $\begin{array}{l}0.308 \\
(0.154)^{* *}\end{array}$ & $\gamma_{1}^{u}$ & $\begin{array}{l}0.372 \\
(0.180)^{* *}\end{array}$ & $\begin{array}{l}0.301 \\
(0.157)^{*}\end{array}$ \\
\hline$D_{t} * \hat{\epsilon}_{t}^{G}$ & $\tilde{\gamma}_{1}$ & $\begin{array}{l}-0.146 \\
(0.318)\end{array}$ & $\begin{array}{l}-0.080 \\
(0.307)\end{array}$ & $\tilde{\gamma}_{1}^{u}$ & $\begin{array}{l}-0.127 \\
(0.316)\end{array}$ & $\begin{array}{l}-0.152 \\
(0.313)\end{array}$ \\
\hline$\hat{\epsilon}_{t}^{T}$ & $\gamma_{2}$ & $\begin{array}{l}0.019 \\
(0.058)\end{array}$ & $\begin{array}{l}0.054 \\
(0.056)\end{array}$ & $\gamma_{2}^{u}$ & $\begin{array}{l}0.024 \\
(0.050)\end{array}$ & $\begin{array}{l}0.062 \\
(0.057)\end{array}$ \\
\hline$D_{t} * \hat{\epsilon}_{t}^{T}$ & $\tilde{\gamma}_{2}$ & $\begin{array}{l}-0.106 \\
(0.161)\end{array}$ & $\begin{array}{l}-0.049 \\
(0.092)\end{array}$ & $\tilde{\gamma}_{2}^{u}$ & $\begin{array}{l}-0.103 \\
(0.144)\end{array}$ & $\begin{array}{l}-0.082 \\
(0.097)\end{array}$ \\
\hline$\Delta \hat{Y}_{t / t-1}$ & $\mu$ & $\begin{array}{l}0.433 \\
(0.065)^{* * *}\end{array}$ & $\begin{array}{l}0.332 \\
(0.059) * * *\end{array}$ & & & \\
\hline$\Delta \hat{Y}_{t / t}$ & & & & $\mu$ & $\begin{array}{l}0.335 \\
(0.052)^{* * *}\end{array}$ & $\begin{array}{l}0.230 \\
(0.048) * * *\end{array}$ \\
\hline Sample & & Indust & Indust & & Indust & Indust \\
\hline No. observations & & 446 & 368 & & 446 & 368 \\
\hline No. countries & & 17 & 19 & & 17 & 19 \\
\hline$R^{2}$ & & 0.325 & 0.333 & & 0.321 & 0.304 \\
\hline Defn. of bad times & & $D 1_{t}(.80)$ & $D 2_{t}(.80)$ & & $D 1_{t}(.80)$ & $D 2_{t}(.80)$ \\
\hline No. of bad times & & 99 & 70 & & 99 & 70 \\
\hline
\end{tabular}

Estimated using Prais-Winston regression assuming disturbances are heteroskedastic and contemporaneously correlated across panels, and allowing for panel-specific first-order autocorrelation. All regressions include year dummies to account for any time-specific effect, i.e. we have a two-way error component regression model. Columns (1) and (2) display estimates of equation (1). Columns (3) and (4) display estimates of equation (2). Standard errors in

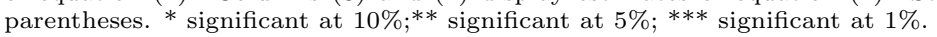




\subsection{Developing Countries}

The results of estimating equations (1) and (2) for developing countries are presented in table 6 . Unlike tables 4 and 5 , we use only the dummy variable $D 2_{t}(.80)$ since there is no available data for constructing dummy variable $D 1_{t}$ for developing countries. ${ }^{9}$ Column (1) shows that the shocks on government consumption have a positive effect on private consumption, with a significant coefficient equal to 0.790 . However, the estimates of $\tilde{\gamma}_{1}$ and the tax variables are insignificantly different from zero. When we analyze the wealth effects on the unconstrained individuals (column (2)), we obtain similar results to those in column (1), i.e. only $\gamma_{1}^{u}$ is significantly different from zero. In this case, the coefficient equals 0.697 and is consistent with the null hypothesis since it is inferior to $\gamma_{1}$.

Concluding, the estimation results for the developing countries do not favor the null hypothesis. Government consumption shocks have Keynesian effects on private consumption during good times as well as bad times. In the case of tax shocks, they do not have any effects on private consumption during either good times or bad times. Besides, the estimation results of equations (1) and (2) are similar, which indicate that the fiscal policy shocks do not affect differently unconstrained and constrained individuals. Therefore, we obtain evidence that reject the expansionary fiscal contraction hypothesis.

Additionally, the results obtained for the developing countries using dummy variable $D 2_{t}(.80)$, are practically equivalent to the ones obtained for the industrial countries. Note, however, that the coefficients $\gamma_{1}$ and $\gamma_{1}^{u}$ are larger when using the sample of developing countries. Therefore, we can conclude that government consumption shocks have a larger Keynesian effect on private consumption in developing countries than in industrial countries. This result is intuitive, and is in accordance with the theoretical model, if we consider that there is a larger proportion of constrained individuals in developing countries.

\section{Consistency Tests}

In order to confirm that the benchmark case results in section 6 are robust, we estimated equations (1) and (2) using alternative definitions of bad times. For both dummy variables, $D 1_{t}$ and $D 2_{t}$, we used two different values to define bad times. Specifically, we used the value of the seventieth and ninetieth percentile of the distribution for each country to define bad times.

The results for the sample of all the countries can be seen in table 7, where we see that the results of the estimations are very similar. The only difference is for the coefficient $\gamma_{1}^{u}$ when using the first definition of bad times $D 1_{t}$. In this case, the coefficient goes from being significant in column (7) to being insignificant in column (8), when using $D 1_{t}(.70)$. However, the coefficient is still significant if we enlarge the confidence level to the $10 \%$. Moreover, when using $D 1_{t}(.90)$ in

\footnotetext{
${ }^{9}$ Specifically, there is only data for Pakistan, South Africa, Thailand and Venezuela.
} 
Table 6: Estimates Developing Countries

\begin{tabular}{lllll}
\hline \hline Var. & Coef. & \multicolumn{1}{c}{$(1)$} & Coef. & \multicolumn{1}{c}{$(2)$} \\
\hline$\hat{\epsilon}_{t}^{G}$ & $\gamma_{1}$ & 0.790 & $\gamma_{1}^{u}$ & 0.697 \\
& & $(0.170)^{* * *}$ & & $(0.172)^{* * *}$ \\
$D_{t} * \hat{\epsilon}_{t}^{G}$ & $\tilde{\gamma}_{1}$ & 0.526 & $\tilde{\gamma}_{1}^{u}$ & 0.320 \\
& & $(0.469)$ & & $(0.440)$ \\
$\hat{\epsilon}_{t}^{T}$ & $\gamma_{2}$ & -0.178 & $\gamma_{2}^{u}$ & -0.174 \\
& & $(0.140)$ & & $(0.137)$ \\
$D_{t} * \hat{\epsilon}_{t}^{T}$ & $\tilde{\gamma}_{2}$ & -0.198 & $\tilde{\gamma}_{2}^{u}$ & -0.277 \\
& & $(0.276)$ & & $(0.253)$ \\
$\Delta \hat{Y}_{t / t-1}$ & $\mu$ & 0.351 & & \\
& & $(0.077)^{* * *}$ & & \\
$\Delta \hat{Y}_{t / t}$ & & & $\mu$ & 0.493 \\
& & & & $(0.054)^{* * *}$ \\
Sample & & & Dev \\
No. observations & & 298 & & 298 \\
No. countries & & 18 & & 18 \\
$R^{2}$ & & 0.290 & & 0.320 \\
Defn. of bad times & & $D 2_{t}(.80)$ & & $D 2_{t}(.80)$ \\
No. of bad times & & 58 & & 58 \\
\hline \hline
\end{tabular}

Estimated using Prais-Winston regression assuming disturbances are heteroskedastic and contemporaneously correlated across panels, and allowing for panel-specific first-order autocorrelation. All regressions include year dummies to account for any time-specific effect, i.e. we have a two-way error component regression model. Column (1) displays estimates of equation (1). Column (2) displays estimates of equation (2). Standard errors in parentheses. ${ }^{*}$ significant at $10 \%$;** significant at $5 \%$; $* *$ significant at $1 \%$. 
Table 7: Other definitions of bad times for all countries

\begin{tabular}{|c|c|c|c|c|c|c|c|}
\hline Var. & Coef. & $\begin{array}{c}(1) \\
D 1_{t}(.80)\end{array}$ & $\begin{array}{c}(2) \\
D 1_{t}(.70)\end{array}$ & $\begin{array}{c}(3) \\
D 1_{t}(.90)\end{array}$ & $\begin{array}{c}(4) \\
D 2_{t}(.80)\end{array}$ & $\begin{array}{c}(5) \\
D 2_{t}(.70)\end{array}$ & $\begin{array}{c}(6) \\
D 2_{t}(.90)\end{array}$ \\
\hline$\hat{\epsilon}_{t}^{G}$ & $\gamma_{1}$ & $\begin{array}{l}0.887 \\
(0.221)^{* * *}\end{array}$ & $\begin{array}{l}0.817 \\
(0.233)^{* * *}\end{array}$ & $\begin{array}{l}0.893 \\
(0.209)^{* * *}\end{array}$ & $\begin{array}{l}0.676 \\
(0.177)^{* * *}\end{array}$ & $\begin{array}{l}0.687 \\
(0.181)^{* * *}\end{array}$ & $\begin{array}{l}0.794 \\
(0.171)^{* * *}\end{array}$ \\
\hline$D_{t} * \hat{\epsilon}_{t}^{G}$ & $\tilde{\gamma}_{1}$ & $\begin{array}{l}0.147 \\
(0.496)\end{array}$ & $\begin{array}{l}0.358 \\
(0.452)\end{array}$ & $\begin{array}{l}0.229 \\
(0.665)\end{array}$ & $\begin{array}{l}0.339 \\
(0.422)\end{array}$ & $\begin{array}{l}0.231 \\
(0.361)\end{array}$ & $\begin{array}{l}-0.509 \\
(0.589)\end{array}$ \\
\hline$\hat{\epsilon}_{t}^{T}$ & $\gamma_{2}$ & $\begin{array}{l}-0.235 \\
(0.093)^{* *}\end{array}$ & $\begin{array}{l}-0.244 \\
(0.104)^{* *}\end{array}$ & $\begin{array}{l}-0.238 \\
(0.085)^{* * *}\end{array}$ & $\begin{array}{l}-0.056 \\
(0.095)\end{array}$ & $\begin{array}{l}-0.052 \\
(0.102)\end{array}$ & $\begin{array}{l}-0.024 \\
(0.087)\end{array}$ \\
\hline$D_{t} * \hat{\epsilon}_{t}^{T}$ & $\tilde{\gamma}_{2}$ & $\begin{array}{l}0.072 \\
(0.212)\end{array}$ & $\begin{array}{l}0.089 \\
(0.173)\end{array}$ & $\begin{array}{l}0.138 \\
(0.282)\end{array}$ & $\begin{array}{l}-0.081 \\
(0.199)\end{array}$ & $\begin{array}{l}-0.077 \\
(0.179)\end{array}$ & $\begin{array}{l}-0.321 \\
(0.248)\end{array}$ \\
\hline$\Delta \hat{Y}_{t / t-1}$ & $\mu$ & $\begin{array}{l}0.492 \\
(0.064)^{* * *}\end{array}$ & $\begin{array}{l}0.491 \\
(0.064)^{* * *}\end{array}$ & $\begin{array}{l}0.491 \\
(0.063)^{* * *}\end{array}$ & $\begin{array}{l}0.364 \\
(0.075)^{* * *}\end{array}$ & $\begin{array}{l}0.362 \\
(0.075)^{* * *}\end{array}$ & $\begin{array}{l}0.361 \\
(0.075)^{* * *}\end{array}$ \\
\hline Sample & & All & All & All & All & All & All \\
\hline $\begin{array}{l}\text { No. obser- } \\
\text { vations }\end{array}$ & & 540 & 540 & 540 & 666 & 666 & 666 \\
\hline $\begin{array}{l}\text { No. coun- } \\
\text { tries }\end{array}$ & & 21 & 21 & 21 & 37 & 37 & 37 \\
\hline$R^{2}$ & & 0.294 & 0.297 & 0.295 & 0.171 & 0.170 & 0.176 \\
\hline $\begin{array}{l}\text { No. of bad } \\
\text { times }\end{array}$ & & 120 & 178 & 61 & 128 & 197 & 66 \\
\hline
\end{tabular}

Estimated using Prais-Winston regression assuming disturbances are heteroskedastic and contemporaneously correlated across panels, and allowing for panel-specific first-order autocorrelation. All regressions include year dummies to account for any time-specific effect, i.e. we have a two-way error component regression model. Columns (1) to (6) display estimates of equation (1). Columns (7) to (12) display estimates of equation (2). See section 7 for alternative definitions of bad times. Standard errors in parentheses. * significant at $10 \%$;** significant at $5 \%$; *** significant at $1 \%$.

column (9), the coefficient is significant at the $5 \%$. Therefore, we conclude that the consistency test lead us to accept the conclusions from the benchmark case.

When only using the sample of industrial countries (table 8) and using the alternative definitions of bad times, we see that the majority of the results do not change. Concretely, the significance of coefficients $\gamma_{1}$ and $\gamma_{1}^{u}$ are the only changes. In the case of $\gamma_{1}$, we see than when we use definition $D 2_{t}(.70)$, it becomes insignificant (column (5)). However, it continues being significant when we use definition $D 2_{t}(.90)$ (column (6)). Besides, from column (8), $\gamma_{1}^{u}$ reduces its significance level from $5 \%$ to $10 \%$ when using the dummy variable $D 1_{t}(.70)$. In addition, when using the second definition of bad times $D 2_{t}(.90)$ in column (12), the coefficient becomes significant at the $5 \%$. Concluding, there is some evidence that the significance of $\gamma_{1}$ and $\gamma_{1}^{u}$ is not completely robust for industrial countries.

For the sample of developing countries (table 9), the results from the benchmark case are practically corroborated in the consistency test. The only difference with the benchmark case can be seen in column (6) for $\gamma_{2}^{u}$. In this case, the coefficient becomes significant at the $5 \%$ with a value of -0.747 . 
Table 7 (continuation): Other definitions of bad times for all countries

\begin{tabular}{llllllll}
\hline \hline Var. & Coef. & \multicolumn{1}{c}{$(7)$} & \multicolumn{1}{c}{$(8)$} & \multicolumn{1}{c}{$(9)$} & \multicolumn{1}{c}{$(10)$} & \multicolumn{1}{c}{$(11)$} & \multicolumn{1}{c}{$(12)$} \\
& & $D 1_{t}(.80)$ & $D 1_{t}(.70)$ & $D 1_{t}(.90)$ & $D 2_{t}(.80)$ & $D 2_{t}(.70)$ & $D 2_{t}(.90)$ \\
\hline$\hat{\epsilon}_{t}^{G}$ & $\gamma_{1}^{u}$ & 0.452 & 0.385 & 0.456 & 0.597 & 0.606 & 0.662 \\
& & $(0.206)^{* *}$ & $(0.218)^{*}$ & $(0.196)^{* *}$ & $(0.172)^{* * *}$ & $(0.176)^{* * *}$ & $(0.166)^{* * *}$ \\
$D_{t} * \hat{\epsilon}_{t}^{G}$ & $\tilde{\gamma}_{1}^{u}$ & 0.135 & 0.329 & 0.252 & 0.103 & 0.050 & -0.569 \\
& & $(0.470)$ & $(0.427)$ & $(0.608)$ & $(0.402)$ & $(0.346)$ & $(0.548)$ \\
$\hat{\epsilon}_{t}^{T}$ & $\gamma_{2}^{u}$ & -0.246 & -0.259 & -0.239 & -0.060 & -0.060 & -0.033 \\
& & $(0.089)^{* * *}$ & $(0.099)^{* * *}$ & $(0.083)^{* * *}$ & $(0.090)$ & $(0.096)$ & $(0.082)$ \\
$D_{t} \hat{\epsilon}_{t}^{T}$ & $\tilde{\gamma}_{2}^{u}$ & 0.055 & 0.091 & 0.029 & -0.150 & -0.118 & -0.395 \\
& & $(0.205)$ & $(0.172)$ & $(0.280)$ & $(0.179)$ & $(0.162)$ & $(0.216)^{*}$ \\
$\Delta \hat{Y}_{t / t}$ & $\mu$ & 0.540 & 0.540 & 0.540 & 0.472 & 0.471 & 0.474 \\
& & $(0.047)^{* * *}$ & $(0.047)^{* * *}$ & $(0.047)^{* * *}$ & $(0.052)^{* * *}$ & $(0.052)^{* * *}$ & $(0.051)^{* * *}$ \\
Sample & & All & All & All & All & All & All \\
No. obser- & & 540 & 540 & 540 & 666 & 666 & 666 \\
vations & & & & & & \\
No. coun- & & 21 & 21 & 21 & 37 & 37 & 37 \\
tries & & & & & & \\
$R^{2}$ & & & & & & & \\
No. of bad & & 120 & 178 & 61 & 128 & 197 & 66 \\
times & & & & & & \\
\hline \hline
\end{tabular}

Estimated using Prais-Winston regression assuming disturbances are heteroskedastic and contemporaneously correlated across panels, and allowing for panel-specific first-order autocorrelation. All regressions include year dummies to account for any time-specific effect, i.e. we have a two-way error component regression model. Columns (1) to (6) display estimates of equation (1). Columns (7) to (12) display estimates of equation (2). See section 7 for alternative definitions of bad times. Standard errors in parentheses. ${ }^{*}$ significant at $10 \%$;** significant at $5 \%$; *** significant at $1 \%$. 
Table 8: Other definitions of bad times for industrial countries

\begin{tabular}{llllllll}
\hline \hline Var. & Coef. & \multicolumn{1}{c}{$(1)$} & \multicolumn{1}{c}{$(2)$} & \multicolumn{1}{c}{$(3)$} & \multicolumn{1}{c}{$(4)$} & \multicolumn{1}{c}{$(5)$} & \multicolumn{1}{c}{$(6)$} \\
& & $D 1_{t}(.80)$ & $D 1_{t}(.70)$ & $D 1_{t}(.90)$ & $D 2_{t}(.80)$ & $D 2_{t}(.70)$ & $D 2_{t}(.90)$ \\
\hline$\hat{\epsilon}_{t}^{G}$ & $\gamma_{1}$ & 0.561 & 0.505 & 0.553 & 0.308 & 0.241 & 0.329 \\
& & $(0.179)^{* * *}$ & $(0.192)^{* * *}$ & $(0.168)^{* * *}$ & $(0.154)^{* *}$ & $(0.167)$ & $(0.149)^{* *}$ \\
$D_{t} * \hat{\epsilon}_{t}^{G}$ & $\tilde{\gamma}_{1}$ & -0.146 & 0.003 & -0.223 & -0.080 & 0.136 & -0.362 \\
& & $(0.318)$ & $(0.308)$ & $(0.380)$ & $(0.307)$ & $(0.256)$ & $(0.500)$ \\
$\hat{\epsilon}_{t}^{T}$ & $\gamma_{2}$ & 0.019 & 0.024 & 0.018 & 0.054 & 0.057 & 0.021 \\
& & $(0.058)$ & $(0.061)$ & $(0.054)$ & $(0.056)$ & $(0.058)$ & $(0.052)$ \\
$D_{t} * \hat{\epsilon}_{t}^{T}$ & $\tilde{\gamma}_{2}$ & -0.106 & -0.091 & -0.159 & -0.049 & -0.045 & 0.082 \\
& & $(0.161)$ & $(0.125)$ & $(0.199)$ & $(0.092)$ & $(0.080)$ & $(0.111)$ \\
$\Delta \hat{Y}_{t / t-1}$ & $\mu$ & 0.433 & 0.433 & 0.431 & 0.332 & 0.333 & 0.334 \\
& & $(0.065)^{* * *}$ & $(0.065)^{* * *}$ & $(0.065)^{* * *}$ & $(0.059)^{* * *}$ & $(0.059)^{* * *}$ & $(0.059)^{* * *}$ \\
Sample & & Indust & Indust & Indust & Indust & Indust & Indust \\
No. obser- & & 446 & 446 & 446 & 368 & 368 & 368 \\
vations & & & & & & & 19 \\
No. coun- & & 17 & 17 & 17 & 19 & 19 & \\
tries & & & & & & & \\
$R^{2}$ & & 0.325 & 0.327 & 0.325 & 0.333 & 0.332 & 0.339 \\
No. of bad & 99 & 148 & 50 & 70 & 110 & 35 \\
times & & & & & & \\
\hline \hline
\end{tabular}

Estimated using Prais-Winston regression assuming disturbances are heteroskedastic and contemporaneously correlated across panels, and allowing for panel-specific first-order autocorrelation. All regressions include year dummies to account for any time-specific effect, i.e. we have a two-way error component regression model. Columns (1) to (6) display estimates of equation (1). Columns (7) to (12) display estimates of equation (2). See section 7 for alternative definitions of bad times. Standard errors in parentheses. * significant at $10 \%$;* significant at $5 \%$;*** significant at $1 \%$. 
Table 8 (continuation): Other definitions of bad times for industrial countries

\begin{tabular}{llllllll}
\hline \hline Var. & Coef. & \multicolumn{1}{c}{$(7)$} & \multicolumn{1}{c}{$(8)$} & \multicolumn{1}{c}{$(9)$} & \multicolumn{1}{c}{$(10)$} & \multicolumn{1}{c}{$(11)$} & \multicolumn{1}{c}{$(12)$} \\
& & $D 1_{t}(.80)$ & $D 1_{t}(.70)$ & $D 1_{t}(.90)$ & $D 2_{t}(.80)$ & $D 2_{t}(.70)$ & $D 2_{t}(.90)$ \\
\hline$\hat{\epsilon}_{t}^{G}$ & $\gamma_{1}^{u}$ & 0.372 & 0.323 & 0.359 & 0.301 & 0.252 & 0.305 \\
& & $(0.180)^{* *}$ & $(0.192)^{*}$ & $(0.163)^{* *}$ & $(0.157)^{*}$ & $(0.168)$ & $(0.151)^{* *}$ \\
$D_{t} * \hat{\epsilon}_{t}^{G}$ & $\tilde{\gamma}_{1}^{u}$ & -0.127 & -0.000 & -0.124 & -0.152 & 0.040 & -0.345 \\
& & $(0.316)$ & $(0.310)$ & $(0.380)$ & $(0.313)$ & $(0.256)$ & $(0.501)$ \\
$\hat{\epsilon}_{t}^{T}$ & $\gamma_{2}^{u}$ & 0.024 & 0.026 & 0.030 & 0.062 & 0.067 & 0.022 \\
& & $(0.050)$ & $(0.055)$ & $(0.048)$ & $(0.057)$ & $(0.059)$ & $(0.054)$ \\
$D_{t} * \hat{\epsilon}_{t}^{T}$ & $\tilde{\gamma}_{2}^{u}$ & -0.103 & -0.076 & -0.216 & -0.082 & -0.076 & 0.069 \\
& & $(0.144)$ & $(0.114)$ & $(0.188)$ & $(0.097)$ & $(0.084)$ & $(0.113)$ \\
$\Delta \hat{Y}_{t / t}$ & $\mu$ & 0.335 & 0.335 & 0.336 & 0.230 & 0.229 & 0.228 \\
& & $(0.052)^{* * *}$ & $(0.052)^{* * *}$ & $(0.052)^{* * *}$ & $(0.048)^{* * *}$ & $(0.048)^{* * *}$ & $(0.048)^{* * *}$ \\
Sample & & Indust & Indust & Indust & Indust & Indust & Indust \\
No. obser- & 446 & 446 & 446 & 368 & 368 & 368 \\
vations & & & & & & \\
No. coun- & & 17 & 17 & 17 & 19 & 19 & 19 \\
tries & & & & & & \\
$R^{2}$ & & 0.321 & 0.320 & 0.324 & 0.304 & 0.304 & 0.306 \\
No. of bad & 99 & 148 & 50 & 70 & 110 & 35 \\
times & & & & & & \\
\hline \hline
\end{tabular}

Estimated using Prais-Winston regression assuming disturbances are heteroskedastic and contemporaneously correlated across panels, and allowing for panel-specific first-order autocorrelation. All regressions include year dummies to account for any time-specific effect, i.e. we have a two-way error component regression model. Columns (1) to (6) display estimates of equation (1). Columns (7) to (12) display estimates of equation (2). See section 7 for alternative definitions of bad times. Standard errors in parentheses. ${ }^{*}$ significant at $10 \%$;** significant at $5 \%$; *** significant at $1 \%$. 
Table 9: Other definitions of bad times for developing countries

\begin{tabular}{|c|c|c|c|c|c|c|c|c|}
\hline Var. & Coef. & $\begin{array}{c}(1) \\
D 2_{t}(.80)\end{array}$ & $\begin{array}{c}(2) \\
D 2_{t}(.70)\end{array}$ & $\begin{array}{c}(3) \\
D 2_{t}(.90)\end{array}$ & Coef. & $\begin{array}{c}(4) \\
D 2_{t}(.80)\end{array}$ & $\begin{array}{c}(5) \\
D 2_{t}(.70)\end{array}$ & $\begin{array}{c}(6) \\
D 2_{t}(.90)\end{array}$ \\
\hline$\hat{\epsilon}_{t}^{G}$ & $\gamma_{1}$ & $\begin{array}{l}0.790 \\
(0.170)^{* * *}\end{array}$ & $\begin{array}{l}0.804 \\
(0.177)^{* * *}\end{array}$ & $\begin{array}{l}0.932 \\
(0.165)^{* * *}\end{array}$ & $\gamma_{1}^{u}$ & $\begin{array}{l}0.697 \\
(0.172)^{* * *}\end{array}$ & $\begin{array}{l}0.700 \\
(0.180)^{* * *}\end{array}$ & $\begin{array}{l}0.776 \\
(0.167)^{* * *}\end{array}$ \\
\hline$D_{t} * \hat{\epsilon}_{t}^{G}$ & $\tilde{\gamma}_{1}$ & $\begin{array}{l}0.526 \\
(0.469)\end{array}$ & $\begin{array}{l}0.380 \\
(0.420)\end{array}$ & $\begin{array}{l}-0.478 \\
(0.586)\end{array}$ & $\tilde{\gamma}_{1}^{u}$ & $\begin{array}{l}0.320 \\
(0.440)\end{array}$ & $\begin{array}{l}0.255 \\
(0.403)\end{array}$ & $\begin{array}{l}-0.439 \\
(0.544)\end{array}$ \\
\hline$\hat{\epsilon}_{t}^{T}$ & $\gamma_{2}$ & $\begin{array}{l}-0.178 \\
(0.140)\end{array}$ & $\begin{array}{l}-0.186 \\
(0.152)\end{array}$ & $\begin{array}{l}-0.119 \\
(0.130)\end{array}$ & $\gamma_{2}^{u}$ & $\begin{array}{l}-0.174 \\
(0.137)\end{array}$ & $\begin{array}{l}-0.185 \\
(0.148)\end{array}$ & $\begin{array}{l}-0.114 \\
(0.127)\end{array}$ \\
\hline$D_{t} * \hat{\epsilon}_{t}^{T}$ & $\tilde{\gamma}_{2}$ & $\begin{array}{l}-0.198 \\
(0.276)\end{array}$ & $\begin{array}{l}-0.147 \\
(0.265)\end{array}$ & $\begin{array}{l}-0.652 \\
(0.337)^{*}\end{array}$ & $\tilde{\gamma}_{2}^{u}$ & $\begin{array}{l}-0.277 \\
(0.253)\end{array}$ & $\begin{array}{l}-0.200 \\
(0.236)\end{array}$ & $\begin{array}{l}-0.747 \\
(0.309)^{* *}\end{array}$ \\
\hline$\Delta \hat{Y}_{t / t-1}$ & $\mu$ & $\begin{array}{l}0.351 \\
(0.077)^{* * *}\end{array}$ & $\begin{array}{l}0.348 \\
(0.077)^{* * *}\end{array}$ & $\begin{array}{l}0.352 \\
(0.073)^{* * *}\end{array}$ & & & & \\
\hline$\Delta \hat{Y}_{t / t}$ & & & & & $\mu$ & $\begin{array}{l}0.493 \\
(0.054)^{* * *}\end{array}$ & $\begin{array}{l}0.494 \\
(0.055)^{* * *}\end{array}$ & $\begin{array}{l}0.498 \\
(0.051) * * *\end{array}$ \\
\hline Sample & & Dev & Dev & Dev & & Dev & Dev & Dev \\
\hline $\begin{array}{l}\text { No. obser- } \\
\text { vations }\end{array}$ & & 298 & 298 & 298 & & 298 & 298 & 298 \\
\hline $\begin{array}{l}\text { No. coun- } \\
\text { tries }\end{array}$ & & 18 & 18 & 18 & & 18 & 18 & 18 \\
\hline$R^{2}$ & & 0.290 & 0.206 & 0.221 & & 0.320 & 0.318 & 0.336 \\
\hline $\begin{array}{l}\text { No. of bad } \\
\text { times }\end{array}$ & & 58 & 87 & 31 & & 58 & 87 & 31 \\
\hline
\end{tabular}

Estimated using Prais-Winston regression assuming disturbances are heteroskedastic and contemporaneously correlated across panels, and allowing for panel-specific first-order autocorrelation. All regressions include year dummies to account for any time-specific effect, i.e. we have a two-way error component regression model. Columns (1) to (3) display estimates of equation (1). Columns (4) to (6) display estimates of equation (2). See section 7 for alternative definitions of bad times. Standard errors in parentheses. ${ }^{*}$ significant at $10 \%$;** significant at $5 \%$; *** significant at $1 \%$. 


\section{Conclusions}

The results from the estimations indicate that government consumption shocks have Keynesian effects on private consumption in industrial and developing countries. In addition, these Keynesian effects are not reverted in bad times. In the case of the tax shocks, the evidence suggest that they do not have any effects on private consumption either in good times or bad times. This result is confirmed for both industrial and developing countries. Accordingly, we show that the composition of fiscal policy shocks is crucial for stimulating private consumption. Contrary to the common belief that expenditure cuts, instead of tax increases, is crucial for a favorable macroeconomic outcome, we claim that the opposite is true. Further, we do not find that initial conditions are important in determining the outcome of fiscal policy. Thus, there is no evidence that favor the expansionary fiscal consolidation hypothesis (non-Keynesian effects). Finally, we find that government consumption shocks have a larger Keynesian effect on private consumption in developing countries than in industrial countries. This result is intuitive, and is in accordance with the theoretical model introduced in section 3, if we consider that there is a larger proportion of constrained individuals in developing countries.

When comparing our results with the results of Schclarek (2003), we get identical results for the case of government consumption shocks, both for industrial and developing countries. In the case of tax shocks, we obtain only coincidences for industrial countries. Schclarek (2003) finds that tax shocks do not have any effects for industrial countries, but, and unlike us, finds Keynesian effects for developing countries. When comparing our results for industrial countries with Perotti (1999), we find markedly differences. He finds that the shocks in government consumption and taxes have Keynesian effects during good times, but non-Keynesian effects during bad times. However, he also finds that the composition of fiscal policy is important. With regards to the other surveyed papers, our results are in line with Giavazzi et al. (2000), Hjelm (2002b) and van Aarle and Garretsen (2003) in the sense that initial conditions, with the exception of preceding depreciations, are not important. Moreover, our results regarding the rejection of the expansionary fiscal consolidation hypothesis are in line with Hjelm (2002a), Hjelm (2002b), van Aarle and Garretsen (2003) and Schclarek (2003). 


\section{References}

Beck, N. and Katz, J. N. (1995). What to do (and not to do) with time-series cross-section data. The American Political Science Review, 89:634-647.

Gavin, M. and Perotti, R. (1997). Fiscal policy in latin america. NBER Macroeconomics Annual, 12:11-62.

Giavazzi, F., Jappelli, T., and Pagano, M. (2000). Searching for non-linear effects of fiscal policy: Evidence from industrial and developing countries. European Economic Review, 44:1259-1289.

Giavazzi, F. and Pagano, M. (1990). Can severe fiscal contractions be expansionary? tales of two small european countries. NBER Macroeconomic Annual, 5:75-110.

Giavazzi, F. and Pagano, M. (1996). Non-keynesian effects of fiscal policy changes: International evidence and the swedish experience. Swedish Economic Policy Review, 3:67-103.

Hemming, R., Kell, M., and Mahfouz, S. (2002). The effectiveness of fiscal policy in stimulating economic activity - a review of the literature. IMF Working Paper No. 02/208, December 2002.

Hjelm, G. (2002a). Effects of fiscal contractions: The importance of preceding exchange rate movements. Scandinavian Journal of Economics, 104(3):423441.

Hjelm, G. (2002b). Is private consumption growth higher (lower) during periods of fiscal contractions (expansions)? Journal of Macroeconomics, 24:17-39.

Jönsson, K. (2004). Fiscal policy regimes and household consumption. Working Papers No. 2004:12, Department of Economics, Lund University, 2004.

McAleer, M. and McKenzie, C. R. (1991). When are two step estimators efficient? Econometric Reviews, 10:235-252.

Murphy, K. M. and Topel, R. H. (1985). Estimation and inference in two-step econometric models. Journal of Business and Economic Statistics, 3:370-379.

Pagan, A. (1984). Econometric issues in the analysis of regressions with generated regressors. International Economic Review, 25:221-247.

Perotti, R. (1999). Fiscal policy in good times and bad. The Quarterly Journal of Economics, 114:1399-1436.

Schclarek, A. (2003). Fiscal policy and private consumption in industrial and developing countries. Working Papers No. 2003:20, Department of Economics, Lund University, 2003. 
Smith, J. and McAleer, M. (1994). Newey-west covariance matrix estimates for models with generated regressors. Applied Economics, 26:635-640.

van Aarle, B. and Garretsen, H. (2003). Keynesian, non-keynesian or no effects of fiscal policy changes? the emu case. Journal of Macroeconomics, 25:213240. 


\section{CESifo Working Paper Series}

(for full list see www.cesifo.de)

1249 Francesco Giavazzi and Guido Tabellini, Economic and Political Liberalizations, July 2004

1250 Yin-Wong Cheung and Jude Yuen, An Output Perspective on a Northeast Asia Currency Union, August 2004

1251 Ralf Elsas, Frank Heinemann, and Marcel Tyrell, Multiple but Asymmetric Bank Financing: The Case of Relationship Lending, August 2004

1252 Steinar Holden, Wage Formation under Low Inflation, August 2004

1253 Ngo Van Long and Gerhard Sorger, Insecure Property Rights and Growth: The Roles of Appropriation Costs, Wealth Effects, and Heterogeneity, August 2004

1254 Klaus Wälde and Pia Weiß, International Competition, Slim Firms and Wage Inequality, August 2004

1255 Jeremy S. S. Edwards and Alfons J. Weichenrieder, How Weak is the Weakest-Link Principle? On the Measurement of Firm Owners' Control Rights, August 2004

1256 Guido Tabellini, The Role of the State in Economic Development, August 2004

1257 François Larmande and Jean-Pierre Ponssard, EVA and the Controllability-congruence Trade-off: An Empirical Investigation, August 2004

1258 Vesa Kanniainen and Jenni Pääkkönen, Anonymous Money, Moral Sentiments and Welfare, August 2004

1259 Panu Poutvaara and Andreas Wagener, Why is the Public Sector More Labor-Intensive? A Distortionary Tax Argument, August 2004

1260 Lars P. Feld and Stefan Voigt, Making Judges Independent - Some Proposals Regarding the Judiciary, August 2004

1261 Joop Hartog, Hans van Ophem, and Simona Maria Bajdechi, How Risky is Investment in Human Capital?, August 2004

1262 Thomas Eichner and Rüdiger Pethig, Efficient Nonanthropocentric Nature Protection, August 2004

1263 David-Jan Jansen and Jakob de Haan, Look Who's Talking: ECB Communication during the First Years of EMU, August 2004

1264 David F. Bradford, The X Tax in the World Economy, August 2004 
1265 Hans-Werner Sinn, Migration, Social Standards and Replacement Incomes. How to Protect Low-income Workers in the Industrialized Countries against the Forces of Globalization and Market Integration, August 2004

1266 Wolfgang Leininger, Fending off one Means Fending off all: Evolutionary Stability in Submodular Games, August 2004

1267 Antoine Bommier and Bertrand Villeneuve, Risk Aversion and the Value of Risk to Life, September 2004

1268 Harrie A. A. Verbon and Lex Meijdam, Too Many Migrants, Too Few Services: A Model of Decision-making on Immigration and Integration with Cultural Distance, September 2004

1269 Thomas Eichner and Rüdiger Pethig, Economic Land Use, Ecosystem Services and Microfounded Species Dynamics, September 2004

1270 Federico Revelli, Performance Rating and Yardstick Competition in Social Service Provision, September 2004

1271 Gerhard O. Orosel and Klaus G. Zauner, Vertical Product Differentiation When Quality is Unobservable to Buyers, September 2004

1272 Christoph Böhringer, Stefan Boeters, and Michael Feil, Taxation and Unemployment: An Applied General Equilibrium Approach, September 2004

1273 Assaf Razin and Efraim Sadka, Welfare Migration: Is the Net Fiscal Burden a Good Measure of its Economics Impact on the Welfare of the Native-Born Population?, September 2004

1274 Tomer Blumkin and Volker Grossmann, Ideological Polarization, Sticky Information, and Policy Reforms, September 2004

1275 Katherine Baicker and Nora Gordon, The Effect of Mandated State Education Spending on Total Local Resources, September 2004

1276 Gabriel J. Felbermayr and Wilhelm Kohler, Exploring the Intensive and Extensive Margins of World Trade, September 2004

1277 John Burbidge, Katherine Cuff and John Leach, Capital Tax Competition with Heterogeneous Firms and Agglomeration Effects, September 2004

1278 Joern-Steffen Pischke, Labor Market Institutions, Wages and Investment, September 2004

1279 Josef Falkinger and Volker Grossmann, Institutions and Development: The Interaction between Trade Regime and Political System, September 2004

1280 Paolo Surico, Inflation Targeting and Nonlinear Policy Rules: The Case of Asymmetric Preferences, September 2004 
1281 Ayal Kimhi, Growth, Inequality and Labor Markets in LDCs: A Survey, September 2004

1282 Robert Dur and Amihai Glazer, Optimal Incentive Contracts for a Worker who Envies his Boss, September 2004

1283 Klaus Abberger, Nonparametric Regression and the Detection of Turning Points in the Ifo Business Climate, September 2004

1284 Werner Güth and Rupert Sausgruber, Tax Morale and Optimal Taxation, September 2004

1285 Luis H. R. Alvarez and Erkki Koskela, Does Risk Aversion Accelerate Optimal Forest Rotation under Uncertainty?, September 2004

1286 Giorgio Brunello and Maria De Paola, Market Failures and the Under-Provision of Training, September 2004

1287 Sanjeev Goyal, Marco van der Leij and José Luis Moraga-González, Economics: An Emerging Small World?, September 2004

1288 Sandro Maffei, Nikolai Raabe and Heinrich W. Ursprung, Political Repression and Child Labor: Theory and Empirical Evidence, September 2004

1289 Georg Götz and Klaus Gugler, Market Concentration and Product Variety under Spatial Competition: Evidence from Retail Gasoline, September 2004

1290 Jonathan Temple and Ludger Wößmann, Dualism and Cross-Country Growth Regressions, September 2004

1291 Ravi Kanbur, Jukka Pirttilä and Matti Tuomala, Non-Welfarist Optimal Taxation and Behavioral Public Economics, October 2004

1292 Maarten C. W. Janssen, José Luis Moraga-González and Matthijs R. Wildenbeest, Consumer Search and Oligopolistic Pricing: An Empirical Investigation, October 2004

1293 Kira Börner and Christa Hainz, The Political Economy of Corruption and the Role of Financial Institutions, October 2004

1294 Christoph A. Schaltegger and Lars P. Feld, Do Large Cabinets Favor Large Governments? Evidence from Swiss Sub-Federal Jurisdictions, October 2004

1295 Marc-Andreas Mündler, The Existence of Informationally Efficient Markets When Individuals Are Rational, October 2004

1296 Hendrik Jürges, Wolfram F. Richter and Kerstin Schneider, Teacher Quality and Incentives: Theoretical and Empirical Effects of Standards on Teacher Quality, October 2004 
1297 David S. Evans and Michael Salinger, An Empirical Analysis of Bundling and Tying: Over-the-Counter Pain Relief and Cold Medicines, October 2004

1298 Gershon Ben-Shakhar, Gary Bornstein, Astrid Hopfensitz and Frans van Winden, Reciprocity and Emotions: Arousal, Self-Reports, and Expectations, October 2004

1299 B. Zorina Khan and Kenneth L. Sokoloff, Institutions and Technological Innovation During Early Economic Growth: Evidence from the Great Inventors of the United States, 1790 - 1930, October 2004

1300 Piero Gottardi and Roberto Serrano, Market Power and Information Revelation in Dynamic Trading, October 2004

1301 Alan V. Deardorff, Who Makes the Rules of Globalization?, October 2004

1302 Sheilagh Ogilvie, The Use and Abuse of Trust: Social Capital and its Deployment by Early Modern Guilds, October 2004

1303 Mario Jametti and Thomas von Ungern-Sternberg, Disaster Insurance or a Disastrous Insurance - Natural Disaster Insurance in France, October 2004

1304 Pieter A. Gautier and José Luis Moraga-González, Strategic Wage Setting and Coordination Frictions with Multiple Applications, October 2004

1305 Julia Darby, Anton Muscatelli and Graeme Roy, Fiscal Federalism, Fiscal Consolidations and Cuts in Central Government Grants: Evidence from an Event Study, October 2004

1306 Michael Waldman, Antitrust Perspectives for Durable-Goods Markets, October 2004

1307 Josef Honerkamp, Stefan Moog and Bernd Raffelhüschen, Earlier or Later: A General Equilibrium Analysis of Bringing Forward an Already Announced Tax Reform, October 2004

1308 M. Hashem Pesaran, A Pair-Wise Approach to Testing for Output and Growth Convergence, October 2004

1309 John Bishop and Ferran Mane, Educational Reform and Disadvantaged Students: Are They Better Off or Worse Off?, October 2004

1310 Alfredo Schclarek, Consumption and Keynesian Fiscal Policy, October 2004 